This document is confidential and is proprietary to the American Chemical Society and its authors. Do not copy or disclose without written permission. If you have received this item in error, notify the sender and delete all copies.

\title{
Integrated plant layout for heat and power cogeneration from diluted bioethanol
}

\begin{tabular}{|r|l|}
\hline Journal: & ACS Sustainable Chemistry \& Engineering \\
\hline Manuscript ID & Sc-2018-00144p.R1 \\
\hline Manuscript Type: & Article \\
\hline Date Submitted by the Author: & n/a \\
\hline Complete List of Authors: & $\begin{array}{l}\text { Tripodi, Antonio; Università degli Studi di Milano, Dip. Chimica } \\
\text { Pizzonia, Antonio; Università degli Studi di Milano, Dip. Chimica } \\
\text { Bahadori, Elnaz; Università degli Studi di Milano, Dip. Chimica } \\
\text { Rossetti, Ilenia; Università degli Studi di Milano, Dip. Chimica }\end{array}$ \\
\hline
\end{tabular}

SCHOLARONE ${ }^{\text {m }}$

Manuscripts 


\title{
Integrated plant layout for heat and power cogeneration from diluted bioethanol
}

\author{
Antonio Tripodi, Antonio Pizzonia, Elnaz Bahadori, Ilenia Rossetti ${ }^{*}$ \\ Chemical Plants and Industrial Chemistry Group, Dip. Chimica, Università degli Studi di Milano, CNR- \\ ISTM and INSTM Unit Milano-Università, via C. Golgi 19, 20133 Milano, Italy
}

\begin{abstract}
A newly developed kinetic model for the steam reforming of bioethanol has been used to simulate a fully integrated bioethanol-to-power plant. The detailed geometrical model of a tube-bundle reformer has been designed, allowing for a reliable rescaling from a molar-scale hydrogen yield to the selected target of 0.45 $0.50 \mathrm{~kg} / \mathrm{h}$. This hydrogen output is suitable to grant electrical (up to $5 \mathrm{~kW}$ ) and thermal (from 5 to $10 \mathrm{~kW}$ ) power supply for distributed micro-generation.

The feedstock cost for this cogeneration plant has been sensibly reduced with respect to other available ethanol reformers proposed in the literature, as the alcohol can be used already mixed with water, i.e. using only partially purified bioethanol. With respect to our previous feasibility studies, the system layout has been further simplified, and a qualitative analysis of the system stability has been performed in relation to a chosen control parameter (i.e. the reformer heat input): the reformer outlet temperature stabilizes at $650{ }^{\circ} \mathrm{C}$ and the fuel cell power at $10.0 \pm 0.5 \mathrm{~kW}$ around a working point that minimizes the oxygen inlet.
\end{abstract}

Keywords: Bioethanol; Steam reforming; Hydrogen production; Heat and power cogeneration; Process simulation.

\footnotetext{
${ }^{*}$ Corresponding author: fax +39-02-50314300; email ilenia.rossetti@unimi.it
} 


\section{List of Acronyms and symbols used}

\begin{tabular}{llll}
\hline CAPEX & Capital Expenses & $C_{p}$ & Constant pressure heat capacity \\
FC & Fuel Cell & $g$ & Catalyst mass \\
MCHP & Micro Cogeneration of Heat and Power & $H$ & Enthalpy \\
OPEX & Operative Expenses & $F$ & Mass flow \\
PEM & Proton-Exchange Membrane & $v$ & Axial velocity \\
WGS & Water-Gas Shift & $Q$ & Thermal power \\
& & $r$ & Reaction rate \\
& $\mathrm{T}$ & Temperature \\
& $\mathrm{U}$ & Overall heat-exchange coefficient \\
& $x$ & FC utilization factor \\
& $y$ & Gas-phase molar fraction
\end{tabular}

\section{Introduction}

Hydrogen production via steam reforming is of growing interest to valorize biomass-derived feedstocks, increasing the number of processes operable with renewable resources ${ }^{1-6}$.

Besides the hydrogen production processes based on methane ${ }^{7,8}$ and methanol ${ }^{9,10}$, those starting from ethanol ${ }^{11}$ can take the advantage of a liquid (easily handled) and non-toxic reactant. In the context of the ethanol-based processes, that range from its direct use as fuel ${ }^{12,13}$ to the production of ethylene ${ }^{14,15}$, the steam reforming process has two interesting features: i) it is very flexible in terms of final products, since the produced hydrogen can be used either as a fuel and as a chemical (in case exploited directly as syngas) ${ }^{16}$; ii) its material yield and energetic input can be tuned varying the water/ethanol ratio in the reacting mixture ${ }^{17}$ and iii) ethanol can be used at low purity levels ${ }^{2,18}$, thus limiting the reactant cost. Indeed, one of the main costs in ethanol production is its purification through azeotropic distillation and molecular sieves. Conventionally, the raw beer is first concentrated through a flash, then rectified to the azeotrope and further dehydrated. The present application allows to exploit directly the mixture outflowing from the first flash distillation, which is by far less expensive than the azeotrope. An economic assessment has quantified the raw material price for first generation ethanol $c$. half than the pure $99.9 \%$ ethanol ${ }^{19-21}$. We have recently addressed the cost estimation of a centralized hydrogen production plant, converting by steam reforming 40,000 ton/year of bioethanol. The minimum selling price of hydrogen (including $10 \%$ rate of return) was calculated as $2.39 € / \mathrm{kg}$. Concerning the $1^{\text {st }}$ generation bioethanol, the use of $90 \%$ purity led to a selling price decreased by $8 \%$ compared to the pure substrate, whereas the use of a $50 \mathrm{wt} \%$ solution led to a $42 \%$ lower price with respect to absolute ethanol ${ }^{22,23}$. Hydrogen produced from second generation bioethanol has a 
higher minimum selling price, $3.70 € / \mathrm{kg}$, due to more expensive biomass treatment. These figures should be compared with other renewable based options for renewable hydrogen, such as nuclear-based water splitting (3.8-5.4 $€ / \mathrm{kg})$, hydropower electrolysis $(5.4-7.9 € / \mathrm{kg})$. A further comparison can be the current hydrogen price from methane steam reforming, not minimum, which is $3-5 € / \mathrm{kg}$.

Moreover, other two aspects contribute to the importance of this raw material. First, the catalysts for ethanol reforming are today an established commercial technology ${ }^{24,25}$. In addition, this alcohol is particularly well posed to meet the large market of distributed consumption, such as the civil and the residential power cogeneration ${ }^{26,27}$, which nowadays is still based on conventional fuels as natural gas ${ }^{28}$ (even when coupled to the FC technology). A mobile ethanol reformer fuel cell system for off-grid power production has been proposed, based on an autothermal reformer, high and low temperature shift reactors, a selective methanation reactor and a tail gas combustor, with size was $250 \mathrm{~W}^{29}$. A slightly bigger size, $1 \mathrm{~kW}$, was addressed elsewhere ${ }^{30}$. The control of an integrated system is a very critical point due to the different time response of the catalytic fuel processor stage and the electrochemical fuel cell part of the plant ${ }^{31}$, as well as the dynamic behaviour $^{32}$. A micro-combined heat and power generation system based on a $10 \mathrm{~kW}$ PEM fuel cell is proposed by Beniasadi et al. ${ }^{33}$, but using natural gas, with consequently higher environmental impact than bioethanol. The efficiency and emissions analysis of a microchip system based on a diesel-fuelled Stirling engine is available ${ }^{27}$, as a comparison with a fuel cells-based system ${ }^{34,35}$.

In this context, we hereby propose an integrated plant for the joint electrical and thermal power production from diluted bioethanol, at the residential scale of $8-11 \mathrm{~kW}$ (with $P_{\text {electical }} \geq 4 \mathrm{~kW}$ ), by routing the produced hydrogen to a fuel cell working at a sufficiently high temperature (not lower than $80{ }^{\circ} \mathrm{C}$ ) to allow significant heat recovery and valorization. This power output distribution is in line with the performance granted nowadays by MCHP systems based on PEM FCs and other primary fuels ${ }^{36}$. The process diagram has been adapted and modified from the schemes of an already existing unit ${ }^{37,38}$, in order to feed the system with a hydro-alcoholic mixture rather than with the separate pure liquids. This allows the direct use of diluted (less expensive) bioethanol. This point is crucial to improve the whole economy of the system and make ethanol competitive with higher power-density fuels such as gasoline: comparative studies suggest, moreover, that only a careful catalyst selection and reactor sizing can overcome potential conversion and selectivity underperformances of alcohols ${ }^{39}$. On the other hand, the use of part of the reformate to sustain the reforming 
reaction has also been studied for FC working with conventional fuels ${ }^{40}$. To obtain a more detailed model on the reformer heat consumption and a more realistic product / byproducts distribution, the reforming reactions have been modeled in detail after extensive kinetic tests on a proprietary catalysts ${ }^{41,42}$, based on $\mathrm{Ni}$ as active phase $^{43}$.

The importance of a detailed kinetic model does not stem only from the interest of loading the reactor with the lowest possible catalyst amount, but also from the need of quantifying precisely un-eliminable byproducts such as methane and $\mathrm{CO}$, that have an impact on the sizing of the water-gas shift and methanation units downstream the steam reformer ${ }^{44}$.

Moreover, steam reforming is run under endothermal conditions (and without oxygen) to maximize hydrogen yield: if the only feedstock to be used is already diluted ethanol, then the reformer must be sustained with part of the produced hydrogen ${ }^{44}$. Such a process layout is more compact, but has less degrees of freedom than the options based on separate fuel and water feeds ${ }^{34,29}$. In this way, the intrinsic interplay between the reformer heat consumption (affecting the hydrogen yield) and its heat supply (deriving from that produced hydrogen itself) can be tackled only relying on a sufficiently detailed reaction kinetics, being otherwise impossible to optimize the heat-exchange inside the reformer.

On this basis, the system presented in this paper has been sized via gross material and heat balances for the auxiliary sections (WGS reactors, fuel cell operation, feed preheating, burner), but with more details at the reformer level. Process simulation has been carried out with Aspen PLUS $^{\circledR}$ V8.8, retrieving the thermodynamic data from the PURE32 databank. The thermodynamic model used is the Peng-Robinson Equation of State, except for several heat exchangers dealing with a substantial liquid fraction of the highly non-ideal ethanol-water mixture, better described by the NRTL method, implementing the Wilson mixing rules. These models showed adequate in predictions, at least in the ranges of compositions here tested.

\section{Models and Methods}

\section{Overall layout}

The general system flow diagram and energy balance are shown in Figures 1 and 2 . 
Figure 1: General layout of the ethanol steam reforming system: the blue line represents the hydroalcoholic mixture, the red line the reformate. The heat recovery between the hot products and the cold feed is represented by the dotted heat-connections.

Figure 2: Block scheme of the energy balance. The purification section (HT- and LT-WGS reactors, methanator, and relative pre-coolers) is omitted and can be considered as summed in the first feed heater shown. The oxygen feeds to the cell and burner are not shown.

With respect to other different reforming schemes ${ }^{34}$ this layout has the following main differences:

a) there is no separate pure fuel input into the system besides the reforming mixture itself: all the heat required to bring the feed up to the reforming temperature and to maintain it through the reactor is derived from the enthalpy content of the feed;

b) the fuel cell efficiency has been reassessed considering two aspects: the partial split of hydrogen to feed the burner (as heat supply to the reformer), the fuel cell efficiency and the fuel utilization factor;

c) the reaction kinetics is as detailed as up-to-date models allow it to be $\left({ }^{41}\right.$ and references therein). It is based on a rigorous modelling and includes important, often neglected byproducts, such as ethylene and acetaldehyde;

d) the partition of the burnt hydrogen into two flue gas currents, one of whom enters the reformer jacket, is explicitly modeled, because this parameter has been chosen as a degree of freedom to tune the system performance. Since the air currents fed to the cell and to the burner are calculated automatically from the relative hydrogen inlets, the only remaining adjustable variables are the ethanol and water contents in the feed.

\section{The fuel cell (FC)}

This component has been modeled as a 'STOICHIOMETRIC REACTOR' block, where only the oxidation of hydrogen is considered and the reaction extent is fixed so to consume part of it. Utilization factors $x=$ 0.65 and 0.8 were tested, based on best and worst cases found in polymer electrolyte membrane fuel cells reports. No other reactions work in this block, because the cell catalysts are supposed as highly selective 
towards hydrogen. All the other chemical species in the reformate are considered as inert (except $\mathrm{CO}$, which is conveniently converted beforehand).

The duty released from this block represents then the useful electric work of the cell, plus the thermal energy removed by a service fluid, according to an efficiency value $(\eta)$ : this ranges typically from 0.3 to 0.5 , so a value of 0.4 has been considered to quantify the electrical power produced. We refer this value to the electric power produced with respect to the oxidation enthalpy of the hydrogen ${ }^{35,45-48}$. The oxygen needed is fed as air. Its flow was automatically calculated through a 'CALCULATOR' block based upon the 'import-export' variables sequencing as the $110 \%$ of the stoichiometric amount to fully convert the hydrogen at the cell inlet. This means that, being the utilization factor $<1$ and the amount of air overstoichiometric, some oxygen is left unused.

\section{Reformate purification}

Before entering the cell, the reformate composition needs to be enriched in hydrogen and above all purified from CO This is accomplished by pushing further the water-gas shift equilibrium thanks to more specific catalysts working in the $250-350{ }^{\circ} \mathrm{C}$ temperature range ${ }^{49}$. The high and low temperature water-gas shift stages have been modeled as 'EQUILIBRIUM' type reactors, more appropriate than Gibbs reactors to describe a chemical equilibrium when only some species are involved. This means that the catalysts are considered not only active, but also selective enough to preferentially accomplish the desired reaction. This is reasonable, being water gas shift (and methanation) very well assessed reactions in the industrial practice and using industrial catalysts under optimized working conditions. The system may for instance rely on a commercial $\mathrm{Fe}_{2} \mathrm{O}_{3} / \mathrm{Cr}_{2} \mathrm{O}_{3} / \mathrm{CuO}$ catalyst for the high temperature step and on $\mathrm{Cu} / \mathrm{ZnO} / \mathrm{Al}_{2} \mathrm{O}_{3}$ for the $\mathrm{LT}$ one. We modelled these reactors by setting only the desired reversible reaction stoichiometries, with the relative thermodynamic data, and typical operating temperatures as in commercial units. Of course, this prevents the possibility to size these units and to evaluate their cost, but these technologies are sufficiently mature to cope with this purification issues.

The residual CO present in the reformate at the low-temperature equilibrium condition is further selectively reduced to $\mathrm{CH}_{4}$ in a methanation reactor, where the following reaction takes place ${ }^{38}$ :

$\mathrm{CO}+3 \mathrm{H}_{2} \rightarrow \mathrm{CH}_{4}+\mathrm{H}_{2} \mathrm{O}$ 
This reaction typically goes to completion and the block type used is then the 'STOICHIOMETRIC' one ${ }^{29}$. A typical commercial catalyst for this step is $\mathrm{Ni} / \mathrm{Al}_{2} \mathrm{O}_{3}$. The residual $\mathrm{CO}$ concentration is below 20 ppmv, as experimentally verified ${ }^{50}$. This step is mandatory due to the poisoning effect of $\mathrm{CO}$ on the fuel cell catalyst ${ }^{51-53}$. The methane so formed is burnt downstream in the burner to supply heat to the reformer, together with the unconverted $\mathrm{H}_{2}$.

The small heat duties of all these reactors, being the WGS and methanation reactions exothermal, are transferred to the feeding mixture. Downstream the methanator, the reformate is cooled below its dew-point to condense and discharge water. The target temperature of the condenser is $50{ }^{\circ} \mathrm{C}$.

\section{Reformer}

Being the core of the process, the reformer has been modeled rigorously, both from the chemical and the thermal points of view, via a 'PLUG-FLOW' block. The reactions are listed in Table 1 and are kinetically modelled following a Langmuir-Hinshelwood-Hougen-Watson approach (LHHW), i.e. their rate takes into account the reactants/products adsorption/desorption on the catalyst. The data used to derive this reaction set, its validation and the kinetic parameters estimation are extensively reported in our previous papers ${ }^{38,41,50}$.

The catalytic system ${ }^{41-43}$ is composed of a Ni-based catalyst, $10 \mathrm{wt} \%$, supported over zirconia and promoted with $\mathrm{K}_{2} \mathrm{O}$. This catalyst revealed among the most active and stable samples in own expertise and compared with the literature. $\mathrm{Ni} / \mathrm{ZrO}_{2}$ catalysts were characterized by strong metal support interaction, which allows to keep the metal dispersed even during high temperature operation. This usually prevents the formation of carbon nanotubes over Ni particles. Furthermore, doping the support with a basic promoter allows to prevent coking due to the acidity of the support, which may promote ethanol dehydration to ethylene and the subsequent polymerization of the latter. The catalyst was stable and active even at very low operating temperature, where the coke accumulation was negligible. Nevertheless, using a conservative approach, kinetic data were derived at relatively high temperature $\left(\mathrm{T}>550^{\circ} \mathrm{C}\right)$, where coke deposition was essentially nil.

The reaction rates are based upon the species molar fraction ' $y$ ' in the gas phase. Capital $K$ letters represent thermodynamic equilibrium constants, lower case ones $(k)$ represent kinetic constants. The denominator term 
is expressed as, where any i-eth term accounts for a reaction intermediate adsorbed on the catalyst, which in turn is related to the gas-species fractions $y_{j}$ via exponents derived from the mechanism. Details on the kinetic data collected are reported elsewhere ${ }^{41,42}$. Briefly, a K-promoted $\mathrm{Ni} / \mathrm{ZrO}_{2}$ sample prepared by flame pyrolysis was tested for ethanol steam reforming at $\mathrm{T}=550-650^{\circ} \mathrm{C}$, water/ethanol $=3-5 \mathrm{~mol} / \mathrm{mol}$ and $\mathrm{GHSV}$ $=25,000-125,000 \mathrm{~h}^{-1}$. These conditions were on purpose very stressing, so to evidence the formation rate of byproducts, such as acetaldehyde and ethylene, which are usually not accounted for in other kinetic models. Data regression was done according with the model summarised in Table 1 . The full details on the regressed parameters is reported elsewhere ${ }^{41}$.

Table 1: Reactions set used to calculate the mass balances along the reformer axis ${ }^{41}$.

Here we point out that, since the reaction rates are derived through a micro-kinetic model (where the reactant of each step is a moiety adsorbed on the catalyst), their dependence from the gas-phase concentrations does not strictly follow the stoichiometry and the adaptation of such models into the ASPEN Plus ${ }^{\circledR}$ calculation schemes may result in several simulation warnings. Within this block, the reaction rates $r$ are used directly to obtain the molar concentrations $y$, for every species, from the simplified steady-state continuity equation:

$v \frac{\partial y}{\partial g}+\sum_{j} r_{j}(T)=0$

where $g$ is the reactor axial length multiplied by the catalyst linear density, $v$ is the relative axial mean velocity (in units coherent with those of $g$ and $r$ ) and the sum is extended every $j$-th reaction relevant for a given chemical, whose rate is calculated for a differential $d g$ quantity automatically selected by the algorithm through the simulation. This corresponds to neglect at this stage the axial and radial diffusions in the gas phase (not important if a fully turbulent flow is developed), and the diffusion of an adsorbed species within the solid phase (not important if the active surface is nearly all exposed).

The above material balance is coupled to the steady-state heat balance (for the reformate):

$C_{p} \frac{\partial T_{r e f}}{\partial g}+\sum_{j} \Delta H_{j}(T)+d U\left(T_{h o t}-T_{r e f}\right)=0$ 
where the mixture heat capacity, reaction heats, fluids temperatures and $d U=u d A$ are re-calculated at every step of the $d g$ coordinate. The large reaction set, together with the complex rate expressions, required to increase the maximum refinement of the integration coordinate up to $10^{4}$ steps. The catalyst loading (180 g of active material) has been chosen rescaling the above cited reaction data (obtained in a test reactor $9 \mathrm{~mm}$ wide, $40 \mathrm{~cm}$ total length) to the presently adopted geometry. Based on the selected reactor geometry, this amount of catalyst can be loaded as wash coated layer on reactor tubes. It should be stressed that this catalyst amount is much lower than what reported in the literature, which led to similar power output with a catalyst loading between 1 and $5 \mathrm{~kg}$ depending on the operating conditions ${ }^{17}$. The present reactor has been here designed to ensure suitable heat-exchange surface between the reacting mixture and the service hot fluid. Assuming a heat exchange coefficient of $17 \mathrm{~W} \times \mathrm{m}^{-2} \times \mathrm{K}^{-138}$, we opted for a layout of 100 tubes, 1 meter long and $7 \mathrm{~mm}$ wide (for an overall surface of $2.2 \mathrm{~m}^{2}$, capable of transferring 3.7 $\mathrm{kW}$ every $100 \mathrm{~K}$ of thermal gradient). The catalyst was designed as a thin coating (few $\mu \mathrm{m}$ ) on the inner walls of the tubes, while the hot flue gases are fed in the shell-side.

The detailed kinetic model employed takes into account also the possible carbon losses as coke, but this species does not leave the reactor, except with a gasification step (not included). Thus, a separator with $100 \%$ efficiency is placed afterwards to achieve congruent mass balances across the reactor and to predict catalyst regeneration steps.

The coke is modeled as a pseudo-component to handle more easily its separation without resorting to separate stream classes or solid substreams. It has the same thermodynamic properties of graphite to account for all reaction enthalpies. Preliminary characterization of the nature of the coke deposed on real catalysts support this choice.

At this stage of process development and due to the fact that the tubes are practically empty, the pressure drops are neglected. The reactor (and the entire line with it) is kept at a pressure of $c a .1$ bar(g) to avoid oxygen leaking and to reduce the volumetric flows without important compression costs.

\section{Heat exchangers and balance}

The heat integration of the system has been designed taking advantage of progressively decreasing temperature from the reformer to the fuel cell. The heat removed downstream the reformer is used to heat up 
and vaporize the feed. All the heat exchangers are specified imposing an outlet temperature for the reformate and the resulting heat duties are transferred to their counterparts upstream the reformer, whose outlet conditions are then automatically determined (Figure 1). Therefore, the couples constituted by the WGS and methanator reactors and a linked heat exchanger represent the sides of a real heat exchanger (or of a cooled reactor). At this stage, the heat exchange surfaces have not been assessed, since the thermal gradients available are always very large $\left(>100^{\circ} \mathrm{C}\right)$.

The last heat recovery before the feed enters into the reactor has been instead modeled as a two-side exchanger through the 'shortcut' options, i.e. the surface calculation is neglected, but the fluid temperatures are modelled rigorously in a counterflow arrangement.

The reformer geometry derives from a compromise between the heat exchange requirements and the catalyst loading. The hot fluid flow in the shell side is adjusted consequently and it is constituted by a fraction of the exhaust exiting from the burner. This exchanger, instead, is fed with all the remixed flue flow, which carries all the thermal energy derived from hydrogen combustion, excluded the duty to the reformer.

Since the role of this heat exchanger is to stabilize the reaction inlet temperature, its exchange surface varies according to the operating conditions and feed dilution. In Figure $3 a$ a first esteem has been reported when selecting a given $U$ value. A final heat exchanger is added, since it represents the degree of freedom to set the final reformer temperature: in this phase, we are only considering steady state simulation, but this latter unit is the key for reliable and stable temperature setting.

Figure 3a-b: Exchanger area needed at constant feed pre-heating condition $\left(567^{\circ} \mathrm{C}\right)$ with different hot fluid moleflow (a, left), with respect to the area calculated for the base case; (b, right) gross fuel cell power as a function of the hot fumes flow to the reformer.

In symbols, denoting with $F$ the species flow before the fuel cell, the energy balance of main blocks reads (Figure 2):

$$
\begin{aligned}
& Q_{\text {burn }} \cong(1-x) F_{H_{2}} \Delta_{o x} H_{H_{2}}+F_{C_{4}} \Delta_{o x} H_{C_{4}} \\
& Q_{\text {cell }}=x F_{H_{2}} \Delta_{o x} H_{H_{2}} \\
& Q_{H X}=Q_{\text {burn }}-Q_{\text {reactor }}-\Delta_{f} H_{\text {flue }}
\end{aligned}
$$


where the suffix $H X$ denotes this particularly important heat recovery (the above balance is valid if the enthalpy of the hot gases exiting the heat exchanger is calculated with respect to that of the burner feed) and the reformer duty can be approximated by the enthalpy yield of at least the following reactions for a known product distribution:

$$
\begin{aligned}
& \text { EtOH }+3 \mathrm{H}_{2} \mathrm{O} \rightarrow 2 \mathrm{CO}_{2}+6 \mathrm{H}_{2} \\
& \text { EtOH } \rightarrow \mathrm{CH}_{4}+\mathrm{CO}+\mathrm{H}_{2} \\
& \text { EtOH } \rightarrow \mathrm{C}_{2} \mathrm{H}_{4}+\mathrm{H}_{2} \mathrm{O}
\end{aligned}
$$

but it is actually calculated rigorously by the PFR block kinetic.

For the overall system:

$$
\Delta_{f} H_{\text {flue }}+Q_{\text {cell }}+Q_{\text {cond }}=F_{E t O H} \Delta_{o x} H_{E t O H}
$$

Notice that in Figure 2, the reactor feed and outlet (tube side) carry the same enthalpy since the reforming heat of reaction is provided by the hot shell-side gases, so the only chemical reaction providing heat to the system is the oxidation of hydrogen, which in this framework is formally equivalent to the oxidation of a stoichiometric equivalent of ethanol. Then the only three power outputs must sum up to this value.

\section{Results}

According to our previous simulations, we have demonstrated the feasibility of using diluted bioethanol solutions to feed a cogeneration unit of the current size ${ }^{17}$. During that investigation we observed a sensitive dependence of system performance and efficiency on the reformer temperature and on the water/ethanol ratio in the feed (see also ${ }^{54}$ ). Both these points are correlated with the heat supply to the system, so that this critical point has been addressed here through a detailed assessment of the heat exchange network and heat recovery throughout the system.

\section{Material and Heat balances}


The material balances for the first chosen operating point $\left(\mathrm{H}_{2}\right.$ utilization factor $\left.\mathrm{x}=0.65\right)$ are reported in Table S1 (Supplementary Information), while the block heat duties follow in Table 2 (refer to Figures 1 and 2). This condition corresponds to a feed dilution water / ethanol $=5 \mathrm{~mol} / \mathrm{mol}$ (i.e. $2 \mathrm{~kg}$ of water $/ \mathrm{kg}$ of ethanol).

Table S1: Stream report (abridged) for the first selected operation point of the power cogeneration plant (stream names in Figure 1).

Table 2: Duties report for the different process blocks as labeled in Figure 1 (negative values stand for released heat). $\mathrm{CU}=$ Cold Utility.

The hydroalcholic feed enthalpy content, calculated as its oxidation took place at the same working temperature of the fuel cell, is $c a .19 \mathrm{~kW}$, so under this assumption the global energetic yield of the reformer-cell system is about the 53\% (the pumping and compression duties are neglected since their sum represent a bare $5 \%$ of the cell power). With a fuel cell efficiency of $40 \%{ }^{45-48,35}$, the electric power yielded and the thermal power recoverable at $80{ }^{\circ} \mathrm{C}$ amount respectively to 4 and $6 \mathrm{~kW}$.

Due to the critical role of the thermal power extracted from the reformate and employed in the reactor jacket, the hot combustion gas flow in the reformer has been chosen as the parameter to evaluate the fuel cell power (Figure $3 b$; see also analysis in the sections below). The trend is weakly increasing from $350 \mathrm{~mol} / \mathrm{h}$ onward, with the cell operating between 9.3 and $10.8 \mathrm{~kW}$ ( \pm 0.7 around the $10 \mathrm{~kW}$ nominal point), while worse system performance is appreciable below $300 \mathrm{~mol} / \mathrm{h}$. The nominal conditions are given for the $35 \%$ of the hot gases produced by the burner going to the reformer ( $c a .450 \mathrm{~mol} / \mathrm{h})$.

\section{$\mathrm{H}_{2}$ utilization factor $x=0.65$}

The hydrogen balance along the system lines is reported in Figure 4a. The relatively little increase after the water-gas shift section is due to the fact that the CO partial pressure in the reformate is already 10 times smaller than the hydrogen one, so the equilibrium value is reached converting very small absolute quantities. The hydrogen exiting from the fuel cell and going to the burner depends straightforwardly on the imposed utilization factor of the fuel cell $\mathrm{x}$. 


\section{$\mathrm{H}_{2}$ utilization factor $\boldsymbol{x}=0.8$}

The key system outputs are reported (Figure $4 b$ ) also for a higher cell utilization factor of $0.8^{48}$; this additional working point has been tested to check the system stability when the burner is left short of hydrogen because a high performance fuel cell is installed. As the hydrogen available to sustain the reactor duty is decreased, the burner temperature decreases from more than $1300{ }^{\circ} \mathrm{C}$ to less than $1200{ }^{\circ} \mathrm{C}$, but the poorer reactor performance is more than compensated by the supposed increase of the cell capacity (Figure 4b). Moreover, provided that the ethanol full conversion is anyway accomplished, the reduced hydrogen yield results mostly in an increased methane flow (recycled as fuel in the burner), from $209.2 \mathrm{~g} / \mathrm{h}(x=0.65)$ to $331.1 \mathrm{~g} / \mathrm{h}(x=0.80)$, so the gross flow exiting the burner undergoes a variation of the $1.3 \%$ only. 
In summary, as the condenser duty is, more or less, equal, in this case one can achieve a better output distribution between the cell and the residual heat of the (now colder) exhaust gases outflowing the regenerative heat-exchanger.

\section{Computational details}

Though there are no proper material recycles, the internal heat exchange taking place all along the feed/product lines determine an energetic loop that has to be solved via the convergence algorithm.

When the $35 \%$ of the reformate going to the burner changes its hydrogen content, both the molar flow and temperature of the flue gases vary appreciably and, considering the relatively low heat capacity of the gases, plus the highly non-linear temperature dependence of the Arrhenius kinetics inside the reactor, the energy recycle of this block becomes critical.

To set the flowsheet convergence on a firmer basis, a preliminary analysis has been carried out. We set an exact copy of the reactor block, with fixed feed temperature and composition, heated by a combustion effluent representative of our system $\left(\mathrm{H}_{2} \mathrm{O}: \mathrm{CO}_{2}: \mathrm{N}_{2}=0.24: 0.11: 0.64\right.$ moles/moles $)$ with freely adjustable flow and temperature. The temperature profiles of the reactor have been analyzed for some significant cases, as shown in Figures $5 a-c$. From these graphs it is possible to check the threshold beyond which the reactor temperature increases too much, leading to an outlet mixture that cannot be treated by the downstream purification section, fuel cell and burner, and to the failing of the flowsheet calculation. Still the different effect of temperature on each reaction rate and the contemporary presence of endothermal and exothermal reactions, in some conditions let the incipient divergence of the kinetic model be stopped (isolated spikes in Figure $5 \mathrm{~b}$ ), as the reformate outlet temperature realigns toward the optimal value of ca. $650{ }^{\circ} \mathrm{C}$. On the other hand, if the flue gases are so cold that the reforming mixture cannot be heated up to at least $600{ }^{\circ} \mathrm{C}$, the calculation can converge, but the system is actually not working. From this analysis, one gets the preliminary information that high flue flows $(\geq 600 \mathrm{~mol} / \mathrm{h})$ and temperatures $\left(\geq 1500^{\circ} \mathrm{C}\right)$ should be avoided.

Figure 5a-b-c: Thermal profiles of the reactor along the axial coordinate at different flue flowrate. Solid line: tube-side, reacting mixture (cold fluid); dotted line: shell-side, service flue gas (hot fluid). Numbers in the legend indicates the hot fluid inlet temperature. In every case, the $\Delta \mathrm{T}$ between the fluids at the exit is $\geq$ 
$15^{\circ} \mathrm{C}$. A too high heat transfer determines inconsistent outlet conditions (the spikes mark the onset of thermal crossover). In all these open-tear simulation, the fuel cell utilization factor is 0.65 .

Even when the reactor block is stable, the overall calculation may still be not: this happens if the burnt gas flows and temperatures (derived by a certain reactor output) keep increasing (or decreasing) steadily at every convergence cycle. Figure 6 shows the flowsheet 'convergence map' based upon the feedback that the purification-cell-burner section provides to the reactor, for a fixed flues-split set to the $35 \%$ value, which helps to identify in advance the region of stable operation of the system and hydrogen yield in those conditions.

Figure 6: Open-tear analysis of the flowsheet based on the reactor hydrogen yield (color scale bar), as function of the fractional enthalpy difference, represented as temperature (dT), and moleflow contributions between the flue gases fed to the reformer and those yielded back after splitting the burned gas. The convergence point is at the $(0,0)$ coordinate. The points shown are obtained for flue flows of 400,500 and $600 \mathrm{~mol} / \mathrm{h}$. Tests lying the I (IV) quadrant let foresee an enthalpy build-up (depletion) within the flue recycle once the tear is closed.

Figure 7 reports an analysis of the additional air needed to oxidize the hydrogen not used by the fuel cell plus the methane (derived from the $\mathrm{CO}$ reduction), on which the burner flow and final temperature depend directly.

Figure 7: Air feed to the burner (calculated so that the oxygen flow is $110 \%$ of the stoichiometric quantity). The zone around $400 \mathrm{~mol} / \mathrm{h}$ is a shallow minimum good for operating purposes.

A code fragment embedded into a 'CALCULATOR' block, provides a dynamic and customized assistance to the convergence algorithm (exploiting the automatic feature of the 'import/export' variables definition in the tear block sequencing): choosing the 'Direct' tear algorithm to rule out any overshooting of the system parameters between successive steps (possibly yielded by the Broyden or un-damped Wittig methods), the 
flue flow to the reactor jacket is reduced if their hydrogen produced is deemed too high and viceversa. This greatly improved the reliability and speed of the calculation procedure, allowing the system to wind up to a stable working point in $5-10$ tear passes starting just from a reasonable reformate mixture content.

The open-tear foreseen reactor conditions and the actual closed-loop system working points are shown in Figures 8 and 9, each one obtained varying the flue split at fixed fuel cell utilization factor $(65 \%)$. It can be noticed that the convergence region extended, closing the recycle, beyond the threshold of $500 \mathrm{~mol} / \mathrm{h}$ flue flow: this is due to the increasing flow of air needed in the burner from $400 \mathrm{~mol} / \mathrm{h}$ up, which causes a dilution of the hot gases with a consequent reduction of the temperature. In this way, the critical condition of having back-flue gases hotter than $1450-1500{ }^{\circ} \mathrm{C}$ is avoided.

Figure 8a-b: Reformer hydrogen yield (a, top) traced at open flue recycle (lines) and then at different convergence conditions. Bottom, b: reformer heat duty at open flue recycle (lines) and then at different convergence conditions.

Figure 9: Outlet temperature from the reformer; lines: open recycle, tube side (solid) and shell side (dashed); points: closed loop, tube (filled) and shell (empty) sides. The ethanol-water inlet temperature is fixed at 567 ${ }^{\circ} \mathrm{C}$.

The large quantity of combusting agent needed at low reactor shell-side flows is due, instead, to the higher methane and ethylene contents in the products under 'colder' and less efficient reforming conditions. Further tests confirm that the closed system is chemically stable for split fractions as high as $50 \%$, yet this block undergoes a mass unbalance of the percent order for split fractions higher than $46 \%$. The above described convergence recovery code makes the calculation converge reproducibly to a split fraction of $43 \%$.

At this point, the selected working condition for the flowsheet has been chosen after the following criteria: i) the hydrogen fraction in the reformate is not far from the maximum achievable, ii) the selected control parameter are slowly (and roughly linearly) varying as the split is open/closed, iii) there still exist operational margins for this blocks (in either direction) and, iv) the air fed to the burner is approaching a minimum. 


\section{Economic considerations}

A full economic assessment of the system is still in progress and substantially needs a reliable evaluation of the fuel cell costs. This is the main weakness since fuel cells are still in a semi-commercial stage to allow a reliable estimation of their costs. A simplified yet indicative analysis of different hydrogen-production options (aimed to provide a FC feed) seem to indicate ethanol as a more promising option than electrolytic methods ${ }^{55}$.

On the ethanol production side, it is reported that the cost of integrated processes starting from biomasses is much more sensitive to the distillation stage (both from the economic and technological point of view) than to the final purification strategies or the type of fermentation substrate ${ }^{56,57}$. Thus, circumventing this problem using a slightly pre-concentrated ethanol is a definitely promising route.

An interesting study links directly the CHP generation at the FC level with the upstream energy consumption of ethanol distillation, indicating that the direct integration between these power outputs/inputs (which is ultimately the key concept behind our proposed layout) can lead to an electrical efficiency of $41 \%$ and an overall efficiency of $54 \%$, in good agreement with our calculations ${ }^{58}$.

As for the fuel processor side, an economic evaluation of a large scale hydrogen production plant has been carried out recently by our group ${ }^{22}$. A system was designed and simulated in Aspen Plus ${ }^{\circledR}$ essentially relying on the same process layout. The main difference was the absence of the fuel cell, since it was conceived for large scale production of pure hydrogen from diluted, second generation bioethanol (40,000 ton/year). The plant was constituted by a steam reformer, two WGS reactors as in the present case, while final hydrogen purification was achieved by pressure swing adsorption rather than methanation. In that case, indeed, high pressure of the produced $\mathrm{H}_{2}$ was desirable to be included in a refueling station, and, hence, also given the plant size, the PSA option revealed more suitable.

Based on these assumptions, the process revealed OPEX sensitive, i.e. its economic sustainability was mainly depending on the operating costs. In particular, the most sensitive parameters were the hydrogen selling prince and bioethanol cost. Such results further underline the importance of the present investigation, which proposes the use of a less expensive bioethanol source. Indeed, when considering the cost of $1^{\text {st }}$ generation bioethanol, the use of $90 \%$ purity led to a selling price decreased by $8 \%$ compared to the $99.9 \%$ purity one, whereas the use of $50 \%$ purity led to a $42 \%$ lower price (data referred to a total production of 
7,793 ton/year of $\mathrm{H}_{2}$ starting from 40,000 ton/year of bioethanol). The economic analysis was repeated considering the $2^{\text {nd }}$ generation bioethanol. The $3.70 € / \mathrm{kg}$ of hydrogen selling price, when produced from $2^{\text {nd }}$ generation bioethanol with $40 \%$ purity, represents a promising result, although in this case the application would be more complex because of the more concerning and less controllable impurities remaining after the fermentation of $2^{\text {nd }}$ generation biomass.

A larger scale hydrogen production (>7000 normal cubic meter/day), when coupled to optimized biomassethanol facilities, can decrease the hydrogen cost to $0.1 \$ / \mathrm{m}^{3}$, making ethanol an automotive primary source even cheaper than methane ${ }^{59}$.

\section{Conclusions}

The original kinetic model here adopted proved robust enough, under the operating temperatures within the range covered during parameter regression carried out in a previous investigation. Indeed, it provided consistent results as the steam-reforming heat input was varied. This is a crucial issue to assess the energy balance of this process, because high hydrogen yields require high heat supply.

The calculation presented shows that the thermal input of an ethanol steam reformer can be provided by a controlled withdraw of the produced hydrogen, without impairing the electricity generation: in this context, ethanol can be effectively used at dilution levels well below the azeotropic threshold, whereas it would not be possible to exploit diluted bioethanol directly as fuels for the burner. This opens the way to the use of less expensive raw materials, thus improving the economic sustainability of the process.

The selected working point for the system foresee the consumption of $3.2 \mathrm{~kg} / \mathrm{h}$ of ethanol and $6.3 \mathrm{~kg} / \mathrm{h}$ of water to obtain a power of $5 \mathrm{~kW}_{\mathrm{el}}$ and not less than $5 \mathrm{~kW}_{\text {th }}$, loading a multi-tubular 1 meter-long reformer with $180 \mathrm{~g}$ of active material. This amount of catalyst is well below the literature values for similar sized systems.

The stability of the working conditions relies on two main chemical aspects:

a) in the first section of the reformer the (exothermal) oxidation of ethanol to acetaldehyde takes place, actually introducing an additional pre-heating to the feed and helping the mixture to remain hot enough until the exit; 
b) the temperature and flow after the auxiliary burner (and then the quality of the reforming conditions) depend not only on the hydrogen draw-off, but also on the residual methane combustion, which makes the overall system less sensitive to the hydrogen fraction in the reformate.

Choosing the partition of the hot utility between the feed pre-heating and the reformer itself as the main adjustable parameter, a wide range of working points has been spanned systematically. The system has proven stable both from the physical and the computational points of view.

Moreover, the fuel cell power never decreased significantly for any tested condition. A utilization factor as low as $65 \%$ has been selected in order to meet the less efficient systems nowadays available on the market, from a conservative point of view, while better results were achieved with higher utilization factor $(x=0.8)$, which however could have induced feeding problems with the burner. Different values of this parameter can in perspective be easily accommodated because: i) a sufficient margin (from 0.35 to at least 0.5 ) exists for the fraction of the hot utility flow to the reformer, that can compensate a lower burner fuel feed; ii) an even larger operative margin exists for the feed pre-heating, since the presently calculated regenerator lets out exhaust gases over $200{ }^{\circ} \mathrm{C}$ hotter than the target cold stream temperature; iii) a suitable working point, with a cell duty increase of $10 \%$ (and a 16\% more air feed to the burner), has already been calculated for a fuel cell with $x=0.80$ without changing the hot flues distribution.

The heat exchange network has been carefully analysed to make the process as much efficient as possible.

\section{Supplementary Information}

Tables are reported including the material balances for a selected operating point $\left(\mathrm{H}_{2}\right.$ utilization factor $\mathrm{x}=0.65)$.

\section{Bibliography}

(1) Xuan, J.; Leung, M. K. H.; Leung, D. Y. C.; Ni, M. A review of biomass-derived fuel processors for fuel cell systems. Renew. Sustain. Energy Rev. 2009, 13 (6-7), 1301-1313.

(2) Remiro, A.; Valle, B.; Oar-arteta, L.; Aguayo, T.; Bilbao, J.; Gayubo, A. G. Hydrogen production by steam reforming of bio-oil and bio-ethanol mixtures in a continuous thermal-catalytic process. Int. $J$. Hydrogen Energy 2014, 39, 6889-6898.

(3) Zou, J.; Yang, H.; Zeng, Z.; Wu, C.; Williams, P. T.; Chen, H. Hydrogen production from pyrolysis catalytic reforming of cellulose in the presence of $\mathrm{K}$ alkali metal. Int. J. Hydrogen Energy 2016, 41 (25), 10598-10607. 
(4) Alvarez, J.; Kumagai, S.; Wu, C.; Yoshioka, T.; Bilbao, J.; Olazar, M.; Williams, P. T. Hydrogen production from biomass and plastic mixtures by pyrolysis-gasification. Int. J. Hydrogen Energy 2014, 39 (21), 10883-10891.

(5) Ma, Z.; Xiao, R.; Zhang, H. Catalytic steam reforming of bio-oil model compounds for hydrogen-rich gas production using bio-char as catalyst. Int. J. Hydrogen Energy 2017, 42 (6), 3579-3585.

(6) Cheekatamarla, P. K.; Finnerty, C. M. Synthesis gas production via catalytic partial oxidation reforming of liquid fuels. Int. J. Hydrogen Energy 2008, 33 (19), 5012-5019.

(7) Bhat, S. A.; Sadhukhan, J. Process Intensification Aspects for Steam Methane Reforming: An Overview. Am. Inst. Chem. Eng. 2009, 55 (2), 408-422.

(8) Hiblot, H.; Ziegler, D.; Fournet, R.; Glaude, P. A. Steam reforming of methane in a synthesis gas from biomass gasification. Int. J. Hydrogen Energy 2016, 41, 18329-18338.

(9) Iulianelli, A.; Ribeirinha, P.; Mendes, A.; Basile, A. Methanol steam reforming for hydrogen generation via conventional and membrane reactors: A review. Renew. Sustain. Energy Rev. 2014, $29,355-368$.

(10) Wang, S.; Wang, S. Exergy analysis and optimization of methanol generating hydrogen system for PEMFC. Int. J. Hydrogen Energy 2006, 31, 1747-1755.

(11) Ni, M.; Leung, D. Y. C.; Leung, M. K. H. A review on reforming bio-ethanol for hydrogen production. Int. J. Hydrogen Energy 2007, 32 (15 SPEC. ISS.), 3238-3247.

(12) Schuster, B. G.; Chinn, M. S. Consolidated Bioprocessing of Lignocellulosic Feedstocks for Ethanol Fuel Production. Bioenergy Resour. 2013, 416-435.

(13) Masum, B. M.; Masjuki, H. H.; Kalam, M. A.; Fattah, I. M. R.; Palash, S. M.; Abedin, M. J. Effect of ethanol - gasoline blend on NOx emission in SI engine. Renew. Sustain. Energy Rev. 2013, 24, 209222.

(14) Horvath, I.; Csefalvay, E.; Mika, L.; Debreczeni, M. Sustainability Metrics for Biomass-Based Carbon Chemicals. ACS Sustain. Chem. Eng. 2017, 5 (3), 2734-2740.

(15) Mohsenzadeh, A.; Zamani, A.; Taherzadeh, M. J. Bioethylene Production from Ethanol : A Review and Techno-economical Evaluation. ChemBio Eng. Rev. 2017, No. 2, 75-91.

(16) Chiu, W. C.; Horng, R. F.; Chou, H. M. Hydrogen production from an ethanol reformer with energy saving approaches over various catalysts. Int. J. Hydrogen Energy 2013, 38 (6), 2760-2769.

(17) Tripodi, A.; Compagnoni, M.; Ramis, G.; Rossetti, I. Process simulation of hydrogen production by steam reforming of diluted bioethanol solutions: Effect of operating parameters on electrical and thermal cogeneration by using fuel cells. Int. J. Hydrogen Energy 2017, 42 (37), 23776.

(18) García-díez, E.; García-labiano, F.; Diego, L. F. De; Abad, A.; Gayán, P.; Adánez, J.; Ruíz, J. A. C. Optimization of hydrogen production with $\mathrm{CO} 2$ capture by autothermal chemical-looping reforming using different bioethanol purities. Appl. Energy 2016, 169, 491-498.

(19) Rossetti, I.; Lasso, J.; Compagnoni, M.; De Guido, G.; Pellegrini, L. H2 production from bioethanol and its use in fuel-cells. Chem. Eng. Trans. 2015, 43, 229-234.

(20) Hernández, L.; Kafarov, V. Process integration of bioethanol from sugar cane and hydrogen production. J. Appl. Sci. 2007, 7 (15), 2015-2019.

(21) Bastidas, P. A.; Gil, I. D.; Rodriguez, G. Comparison of the main ethanol dehydration technologies through process simulation. 20th Eurpean Symp. Comput. aided Process Eng. - ESCAPE20 2010, 16. 
(22) Compagnoni, M.; Mostafavi, E.; Tripodi, A.; Mahinpey, N.; Rossetti, I. Techno-economic analysis of a bioethanol to hydrogen centralized plant. Energy\&Fuels 2017, 31 (11), 12988-12996.

(23) Compagnoni, M.; Tripodi, A.; Mostafavi, E.; Mahinpey, N.; Rossetti, I. Hydrogen production by steam reforming of bio-ethanol: Process design and economic assessment. In DGMK Tagungsbericht; 2017; Vol. 2017.

(24) Akpan, E.; Akande, A.; Aboudheir, A.; Ibrahim, H.; Idem, R. Experimental, kinetic and 2-D reactor modeling for simulation of the production of hydrogen by the catalytic reforming of concentrated crude ethanol ( CRCCE ) over a Ni-based commercial catalyst in a packed-bed tubular reactor. Chem. Eng. Sci. 2007, 62, 3112-3126.

(25) Mathure, P. V.; Ganguly, S.; Patwardhan, A. V.; Saha, R. K. Steam reforming of ethanol using a commercial nickel-based catalyst. Ind. Eng. Chem. Res. 2007, 46 (25), 8471-8479.

(26) Lanzini, A.; Santarelli, M.; Orsello, G. Residential Solid Oxide Fuel Cell Generator Fuelled by Ethanol: Cell, Stack and System Modelling with a Preliminary Experiment. Fuel Cells 2010, No. 4, 654-675.

(27) Farra, N.; Tzanetakis, T.; Thomson, M. J. Experimental Determination of the Efficiency and Emissions of a Residential Microcogeneration System Based on a Stirling Engine and Fueled by Diesel and Ethanol. Energy \& Fuels 2012, 26, 889-900.

(28) Rosato, A.; Sibilio, S.; Ciampi, G. Energy, environmental and economic dynamic performance assessment of different micro-cogeneration systems in a residential application. Appl. Therm. Eng. 2013, 59 (1-2), 599-617.

(29) Aicher, T.; Full, J.; Schaadt, A. A portable fuel processor for hydrogen production from ethanol in a $250 \mathrm{Wel}$ fuel cell system. Int. J. Hydrogen Energy 2009, 34 (19), 8006-8015.

(30) Bujlo, P.; Pasupathi, S.; Ulleberg; Scholta, J.; Nomnqa, M. V.; Rabiu, a.; Pollet, B. G. Validation of an externally oil-cooled $1 \mathrm{kWel}$ HT-PEMFC stack operating at various experimental conditions. Int. J. Hydrogen Energy 2013, 38 (23), 9847-9855.

(31) Biset, S.; Nieto Deglioumini, L.; Basualdo, M.; Garcia, V. M.; Serra, M. Analysis of the control structures for an integrated ethanol processor for proton exchange membrane fuel cell systems. $J$. Power Sources 2009, 192 (1), 107-113.

(32) Jahn, H.-J.; Schroer, W. Dynamic simulation model of a steam reformer for a residential fuel cell power plant. J. Power Sources 2005, 150, 101-109.

(33) Baniasadi, E.; Toghyani, S.; Afshari, E. Exergetic and exergoeconomic evaluation of a trigeneration system based on natural gas-PEM fuel cell. Int. J. Hydrogen Energy 2017, 42 (8), 5327-5339.

(34) Francesconi, J. a.; Mussati, M. C.; Mato, R. O.; Aguirre, P. a. Analysis of the energy efficiency of an integrated ethanol processor for PEM fuel cell systems. J. Power Sources 2007, 167 (1), 151-161.

(35) Giunta, P.; Mosquera, C.; Amadeo, N.; Laborde, M. Simulation of a hydrogen production and purification system for a PEM fuel-cell using bioethanol as raw material. J. Power Sources 2007, 164 (1), 336-343.

(36) Murugan, S.; Horák, B. A review of micro combined heat and power systems for residential applications. Renew. Sustain. Energy Rev. 2016, 64, 144-162.

(37) Rossetti, I.; Compagnoni, M.; Torli, M. Process simulation and optimisation of $\mathrm{H} 2$ production from ethanol steam reforming and its use in fuel cells. 1. Thermodynamic and kinetic analysis. Chem. Eng. J. 2015, 281, 1024-1035.

(38) Rossetti, I.; Compagnoni, M.; Torli, M. Process simulation and optimization of $\mathrm{H} 2$ production from 
ethanol steam reforming and its use in fuel cells . 2 . Process analysis and optimization. Chem. Eng. J. 2015, 281, 1036-1044.

(39) Nilsson, M.; Karatzas, X.; Lindström, B.; Pettersson, L. J. Assessing the adaptability to varying fuel supply of an autothermal reformer. Chem. Eng. J. 2008, 142 (3), 309-317.

(40) Hawkes, A. D.; Aguiar, P.; Croxford, B.; Leach, M. A.; Adjiman, C. S.; Brandon, N. P. Solid oxide fuel cell micro combined heat and power system operating strategy: Options for provision of residential space and water heating. J. Power Sources 2007, 164 (1), 260-271.

(41) Tripodi, A.; Compagnoni, M.; Rossetti, I. Kinetic modeling and reactor simulation for ethanol steam reforming. ChemCatChem 2016, 8, $3804-3813$.

(42) Compagnoni, M.; Tripodi, A.; Rossetti, I. Parametric study and kinetic testing for ethanol steam reforming. Appl. Catal. B Environ. 2016, 203, 899-909.

(43) Compagnoni, M.; Tripodi, A.; Di Michele, A.; Sassi, P.; Signoretto, M.; Rossetti, I. Low temperature ethanol steam reforming for process intensification: New Ni/MxO-ZrO2 active and stable catalysts prepared by flame spray pyrolysis. Int. J. Hydrogen Energy 2017, 42 (47), 28193-28213.

(44) Oakley, J. H.; Hoadley, a. F. a. Industrial scale steam reforming of bioethanol: A conceptual study. Int. J. Hydrogen Energy 2010, 35 (16), 8472-8485.

(45) Barbir, F.; Gomez, T. Efficiency and Economics of Proton Exchange Membrane (PEM) Fuel Cells. Int. J. Hydrogen Energy 1997, 22, 1027-1037.

(46) Ratlamwala, T. A. H.; El-Sinawi, A. H. El; Gadalla, M. A.; Aidan, A. Performance analysis of a new designed PEM fuel cell. Int. J. ENERGY Res. 2012, 36, 1121-1132.

(47) Dokkar, B.; Negrou, B.; Settou, N.; Imine, O.; Chennouf, N.; Benmhidi, A. Optimization of PEM fuel cells for PV-Hydrogen power system. Energy Procedia 2013, 36, 798-807.

(48) König, P.; Ivers-Tiffèe, E. Increase of the fuel cell system efficiency — Modular testing, analysis and development environment. J. Power Sources 2009, 190, 121-132.

(49) Choi, Y.; Stenger, H. G. Water gas shift reaction kinetics and reactor modeling for fuel cell grade hydrogen. J. Power Sources 2003, 124 (2), 432-439.

(50) Rossetti, I.; Biffi, C.; Tantardini, G. F.; Raimondi, M.; Vitto, E.; Alberti, D. 5 kW e + 5 kW t reformer-PEMFC energy generator from bioethanol first data on the fuel processor from a demonstrative project. Int. J. Hydrogen Energy 2012, 37 (10), 8499-8504.

(51) Kunusch, C.; Puleston, P.; Mayosky, M. Sliding-Mode Control of PEM Fuel Cells. In Sliding-Mode Control of PEM Fuel Cells; Springer, 2012; pp 13-33.

(52) Farrell, C. G.; Gardner, C. L.; Ternan, M. Experimental and modelling studies of CO poisoning in PEM fuel cells. J. Power Sources 2007, 171, 282-293.

(53) Cheng, X.; Shi, Z.; Glass, N.; Zhang, L.; Zhang, J.; Song, D.; Liu, Z.; Wang, H.; Shen, J. A review of PEM hydrogen fuel cell contamination: Impacts, mechanisms, and mitigation. J. Power Sources 2007, 165, 739-756.

(54) Rossetti, I.; Lasso, J.; Compagnoni, M.; Guido, G. De. H 2 Production from Bioethanol and its Use in Fuel-Cells. Chem. Eng. Trans. 2015, 43 (2013), 229-234.

(55) Hwang, J.-J. Sustainability study of hydrogen pathways for fuel cell vehicle applications. Renew. Sustain. Energy Rev. 2013, 19, 220-229.

(56) Ebrahimiaqda, E.; Ogden, K. L. Simulation and Cost Analysis of Distillation and Purification Step in Production of Anhydrous Ethanol from Sweet Sorghum. ACS Sustain. Chem. Eng. 2017, 5 (8), 6854 
2

3

4

5

6

7

8

9

10

11

12

13

14

15

16

17

18

19

20

21

22

23

24

25

26

27

28

29

30

31

32

33

34

35

36

37

38

39

40

41

42

43

44

45

46

47

48

49

50

51

52

53

54

55

56

57

58

59

60

6862.

(57) Kiss, A. A.; Ignat, R. M. Optimal Economic Design of an Extractive Distillation Process for Bioethanol Dehydration. Energy Technol. 2013, 1 (2), 166-170.

(58) Jamsak, W.; Douglas, P. L.; Croiset, E.; Suwanwarangkul, R.; Laosiripojana, N.; Charojrochkul, S.; Assabumrungrat, S. Design of a thermally integrated bioethanol-fueled solid oxide fuel cell system integrated with a distillation column. J. Power Sources 2009, 187 (1), 190-203.

(59) Silveira, J. L.; Braga, L. B.; de Souza, A. C. C.; Antunes, J. S.; Zanzi, R. The benefits of ethanol use for hydrogen production in urban transportation. Renew. Sustain. Energy Rev. 2009, 13 (9), 25252534. 


\section{TABLES}

Table 1: Reactions set used to calculate the mass balances along the reformer axis ${ }^{41}$.

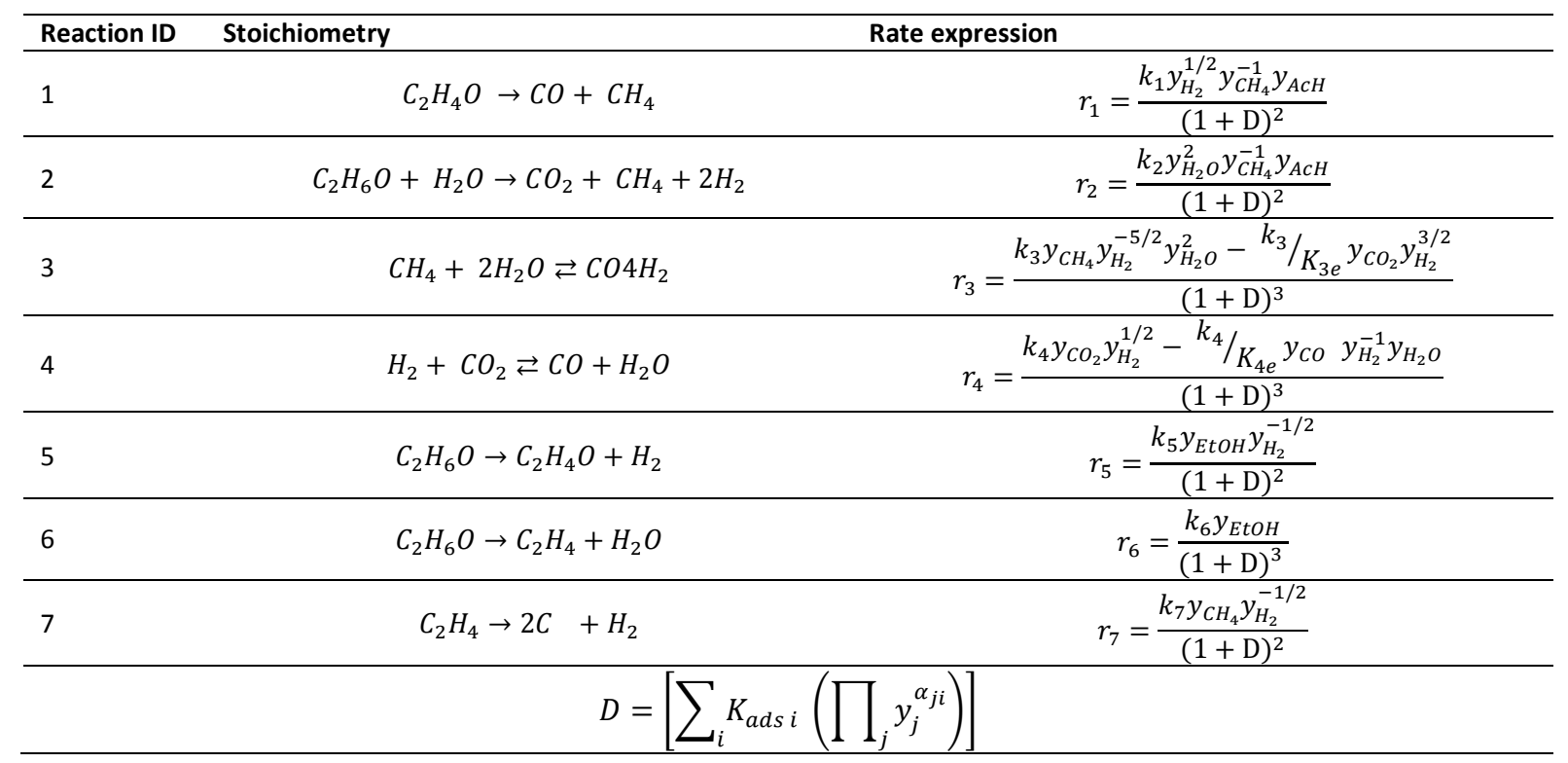


1

2

3

4

5

6

7

8

9

10

11

12

13

14

15

16

17

18

19

20

21

22

23

24

25

26

27

28

29

30

31

32

33

34

35

36

37

38

39

40

41

42

43

44

45

46

47

48

49

50

51

52

53

54

55

56

57

58

59

60

Table 2: Duties report for the different process blocks as labeled in Figure 1 (negative values stand for released heat). $\mathrm{CU}=$ Cold Utility.

\begin{tabular}{|c|c|c|c|c|c|c|c|c|c|c|c|}
\hline Block & SRE & $\begin{array}{l}\text { XHTWG } \\
\mathrm{S}\end{array}$ & $\begin{array}{l}\text { XLTWG } \\
\mathrm{S}\end{array}$ & XMET & COND & $\begin{array}{l}\text { FUELCEL } \\
\text { L }\end{array}$ & $\begin{array}{l}\text { BURNE } \\
\text { R }\end{array}$ & $\begin{array}{l}\text { AUTOH } \\
x\end{array}$ & REC15 & REC13 & REC11 \\
\hline Type & $\begin{array}{l}\text { Plug- } \\
\text { flow } \\
\text { reactor }\end{array}$ & $\begin{array}{l}\text { One- } \\
\text { side } \\
\text { exchang } \\
\text { er }\end{array}$ & $\begin{array}{l}\text { One- } \\
\text { side } \\
\text { exchang } \\
\text { er }\end{array}$ & $\begin{array}{l}\text { One- } \\
\text { side } \\
\text { exchang } \\
\text { er }\end{array}$ & $\begin{array}{l}\text { Vap-Liq } \\
\text { Separat } \\
\text { or }\end{array}$ & $\begin{array}{l}\text { Stoich. } \\
\text { Reactor }\end{array}$ & $\begin{array}{l}\text { Gibbs } \\
\text { Reactor }\end{array}$ & $\begin{array}{l}\text { Two- } \\
\text { side } \\
\text { exchang } \\
\text { er }\end{array}$ & $\begin{array}{l}\text { One- } \\
\text { side } \\
\text { exchang } \\
\text { er }\end{array}$ & $\begin{array}{l}\text { One- } \\
\text { side } \\
\text { exchang } \\
\text { er }\end{array}$ & $\begin{array}{l}\text { One- } \\
\text { side } \\
\text { exchang } \\
\text { er }\end{array}$ \\
\hline $\begin{array}{l}\text { Duty } \\
\text { (kW) }\end{array}$ & 3.29 & -1.90 & -0.43 & -0.42 & -3.73 & -10.12 & 0.00 & 5.09 & 1.90 & -0.43 & -0.42 \\
\hline $\begin{array}{l}\text { Proce } \\
\text { ss }\end{array}$ & $\begin{array}{l}\text { Reform } \\
\text { ate }\end{array}$ & $\begin{array}{l}\text { Reform } \\
\text { ate }\end{array}$ & $\begin{array}{l}\text { Reform } \\
\text { ate }\end{array}$ & $\begin{array}{l}\text { Reform } \\
\text { ate }\end{array}$ & $\begin{array}{l}\text { Reform } \\
\text { ate }\end{array}$ & $\begin{array}{l}\text { Reform } \\
\text { ate }\end{array}$ & $\begin{array}{l}\text { Reform } \\
\text { ate + }\end{array}$ & $\begin{array}{l}\text { Feed } \\
110\end{array}$ & $\begin{array}{l}- \\
-\end{array}$ & $\begin{array}{l}- \\
-\end{array}$ & $\begin{array}{l}- \\
-\end{array}$ \\
\hline fluid & $567-$ & $643-$ & $350-$ & $280-$ & $210-$ & $50-80$ & spent & 567 & & & \\
\hline $\begin{array}{l}\mathrm{T}_{\text {in }}- \\
\mathrm{T}_{\text {out }} \\
\left({ }^{\circ} \mathrm{C}\right)\end{array}$ & 643 & 350 & 280 & 210 & 50 & & $\begin{array}{ll}80 & - \\
1322 & \end{array}$ & & & & \\
\hline Servic & burned & Feed & Feed & Feed & - & - & None & Burned & - & - & - \\
\hline $\begin{array}{l}\text { e } \\
\text { Fluid }\end{array}$ & $\begin{array}{l}\text { gas } \\
1322 \quad-\end{array}$ & $\begin{array}{l}103 \\
110\end{array}-$ & $\begin{array}{ll}71 & - \\
102\end{array}$ & $26-69$ & - & - & - & $\begin{array}{l}\text { gas } \\
1097 \quad-\end{array}$ & - & - & - \\
\hline $\begin{array}{l}\mathrm{T}_{\text {in }}- \\
\mathrm{T}_{\text {out }} \\
\left({ }^{\circ} \mathrm{C}\right)\end{array}$ & 656 & & & & & & & 733 & & & \\
\hline Notes & & & & & $\begin{array}{l}\text { Needs } \\
\mathrm{CU}\end{array}$ & $\begin{array}{l}\text { Needs } \\
\mathrm{CU}\end{array}$ & & & $\begin{array}{l}\text { Coupled } \\
\text { to } \\
\text { XHTWG } \\
\text { S }\end{array}$ & $\begin{array}{l}\text { Coupled } \\
\text { to } \\
\text { XLTWG } \\
\text { S }\end{array}$ & $\begin{array}{l}\text { Coupled } \\
\text { to } \\
\text { XMET }\end{array}$ \\
\hline
\end{tabular}


FIGURES

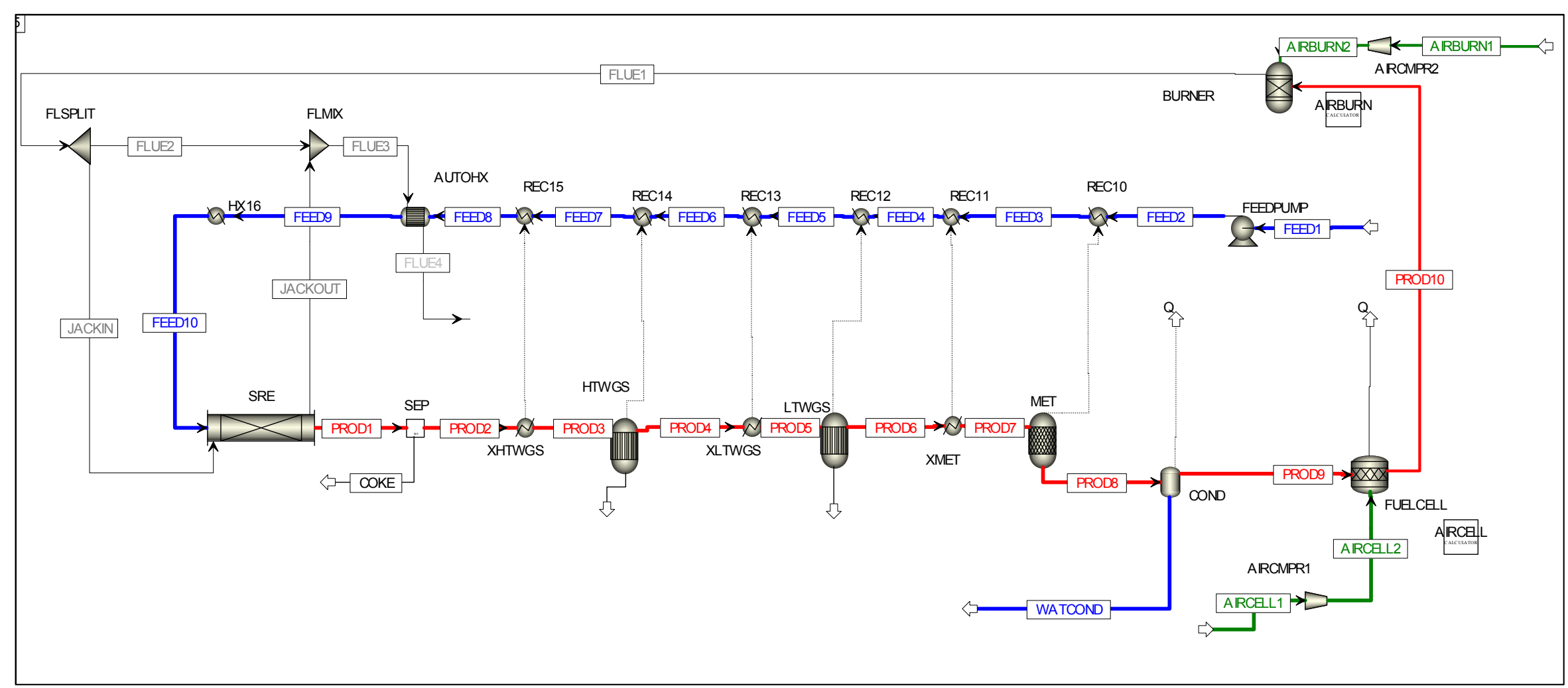

Figure 1: General layout of the ethanol steam reforming system: the blue line represents the hydroalcoholic mixture, the red line the reformate. The heat recovery between the hot products and the cold feed is represented by the dotted heat-connections. 


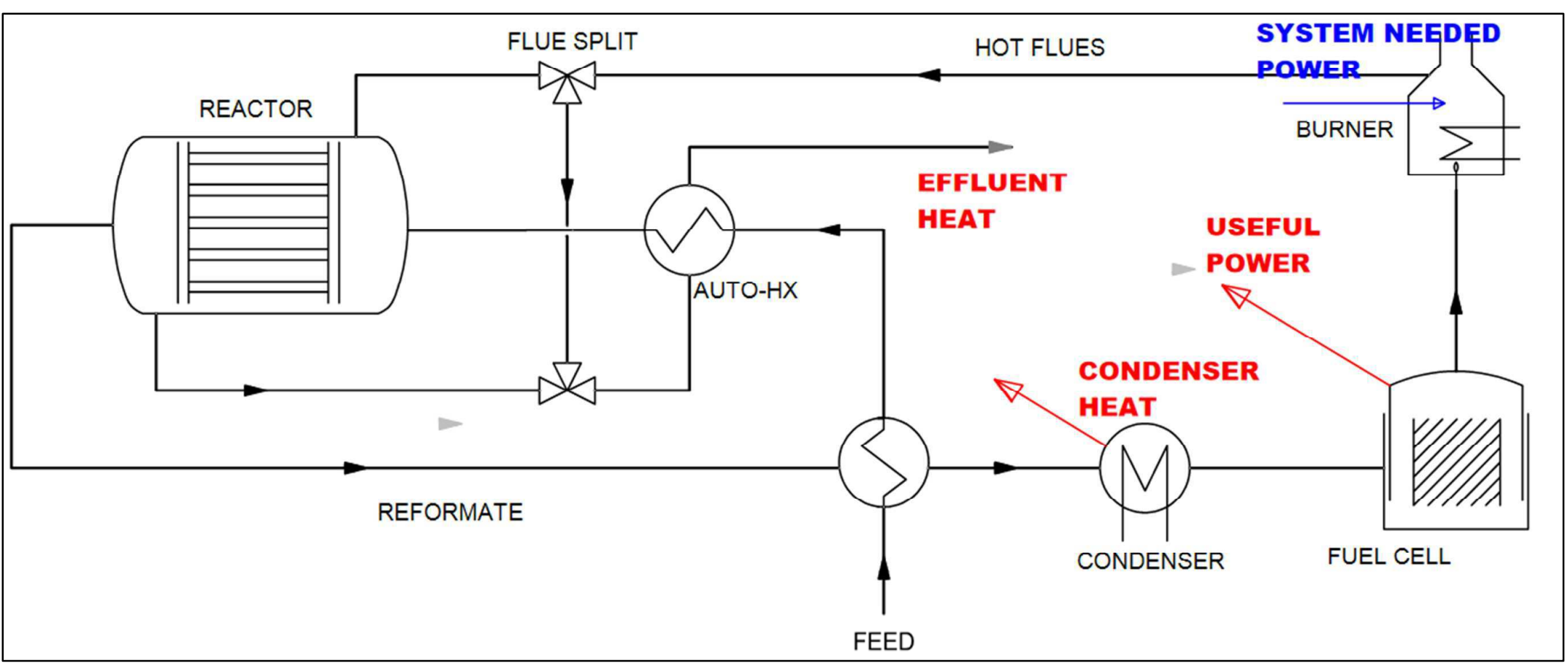

Figure 2: Block scheme of the energy balance. The purification section (HT- and LT-WGS reactors, methanator, and relative pre-coolers) is omitted and can be considered as summed in the first feed heater shown. The oxygen feeds to the cell and burner are not shown. 
b)
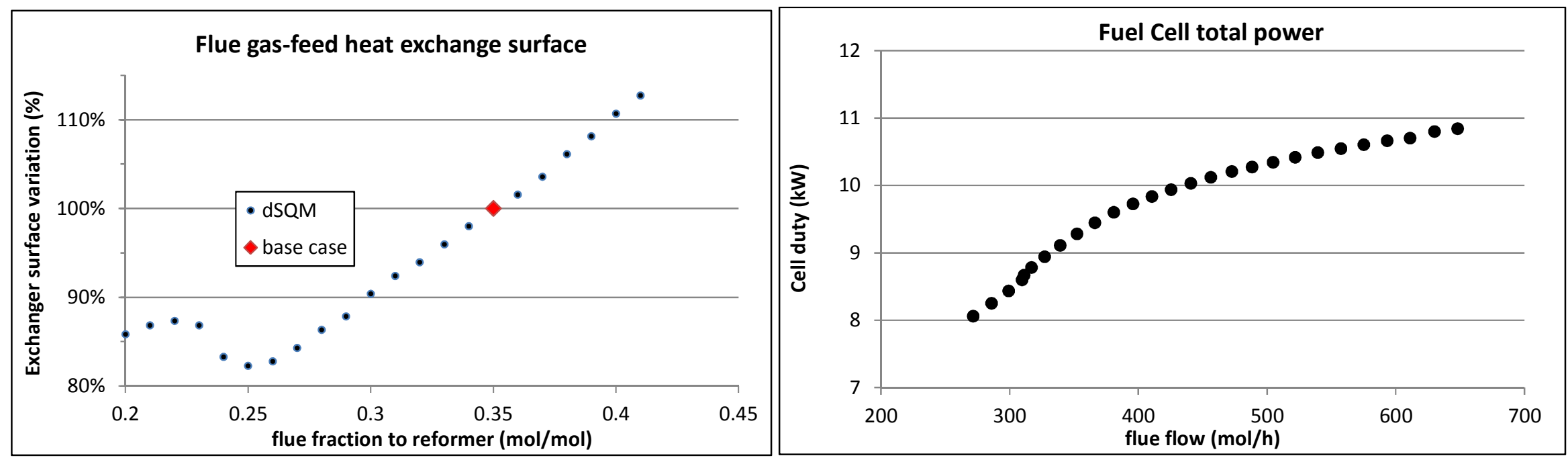

Figure 3a-b: Exchanger area needed at constant feed pre-heating condition $\left(567^{\circ} \mathrm{C}\right)$ with different hot fluid moleflow (a, left), with respect to the area calculated for the base case; (b, right) gross fuel cell power as a function of the hot fumes flow to the reformer. 
a)

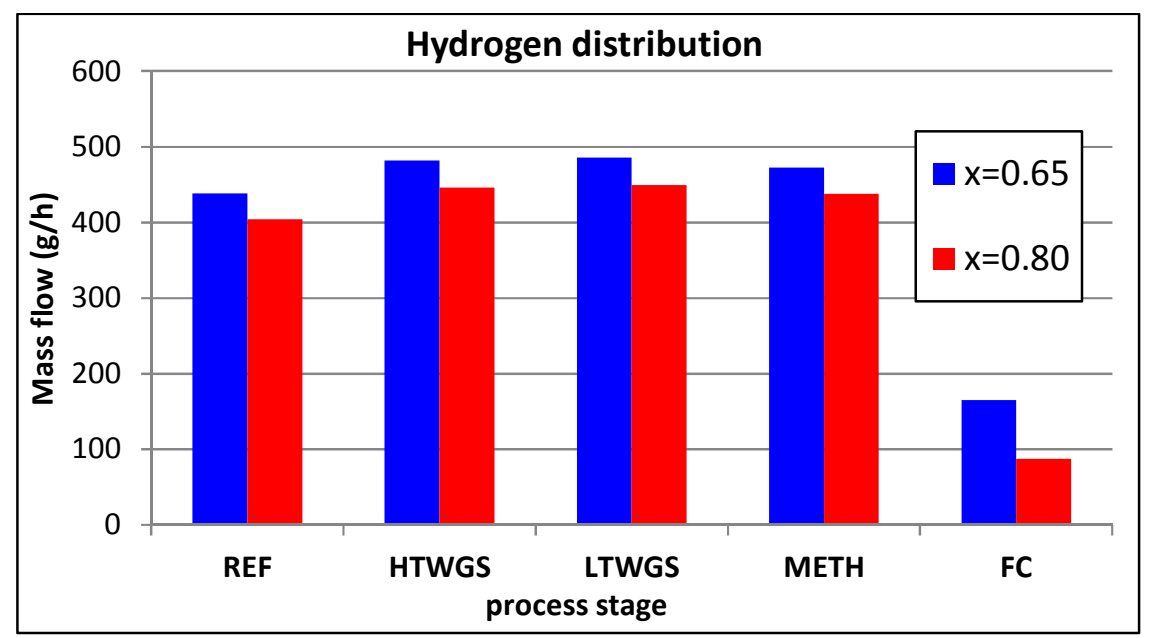

b)

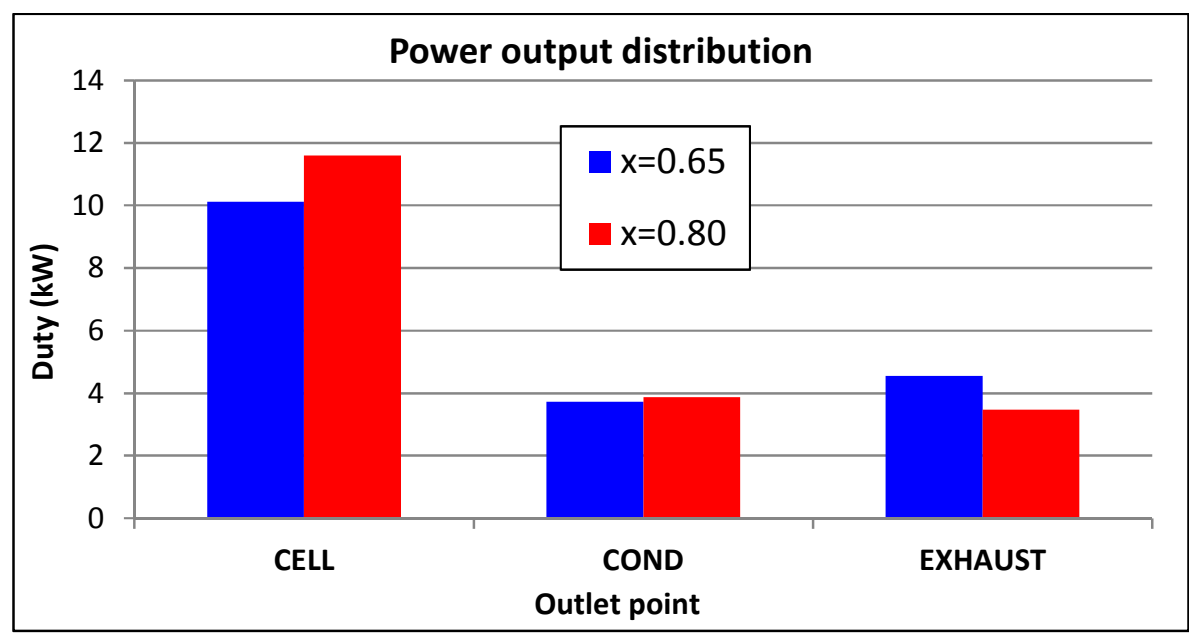

Figure 4a-b: Hydrogen flow within the system, traced at the various blocks exit (a, left), and power extracted (b, right) as fuel cell total power, water-separator heat duty and enthalpy carried by the effluents heat (Exhaust). In every case, $35 \%$ of the combustion gases flow to the reactor. 
a)

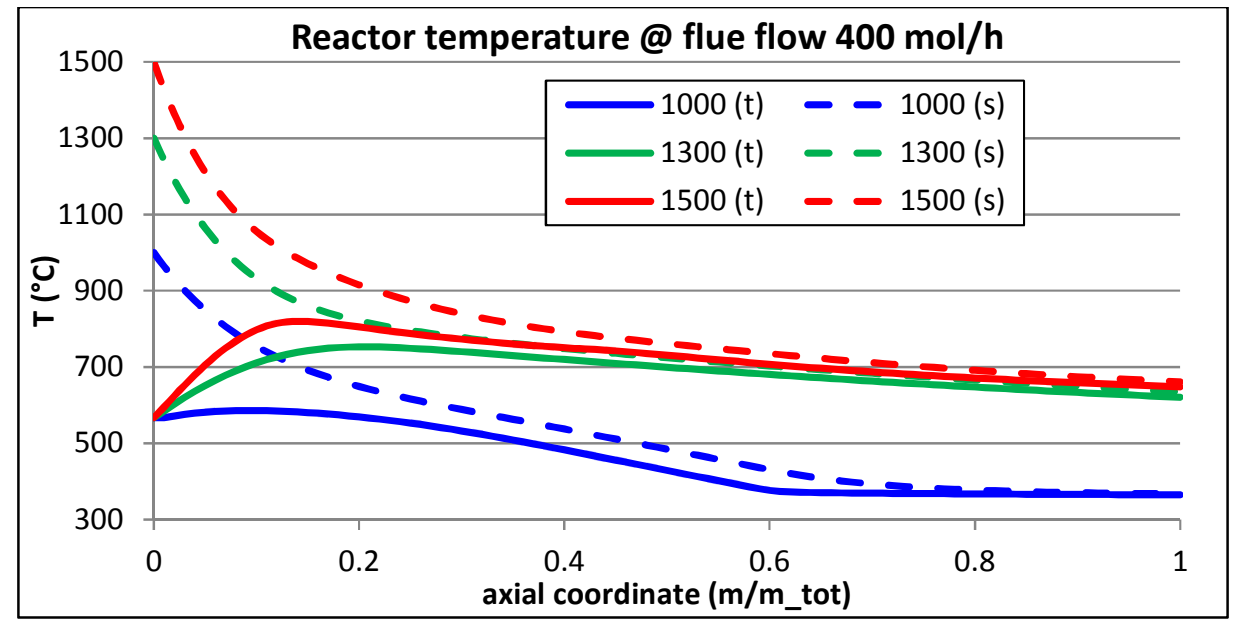

b)

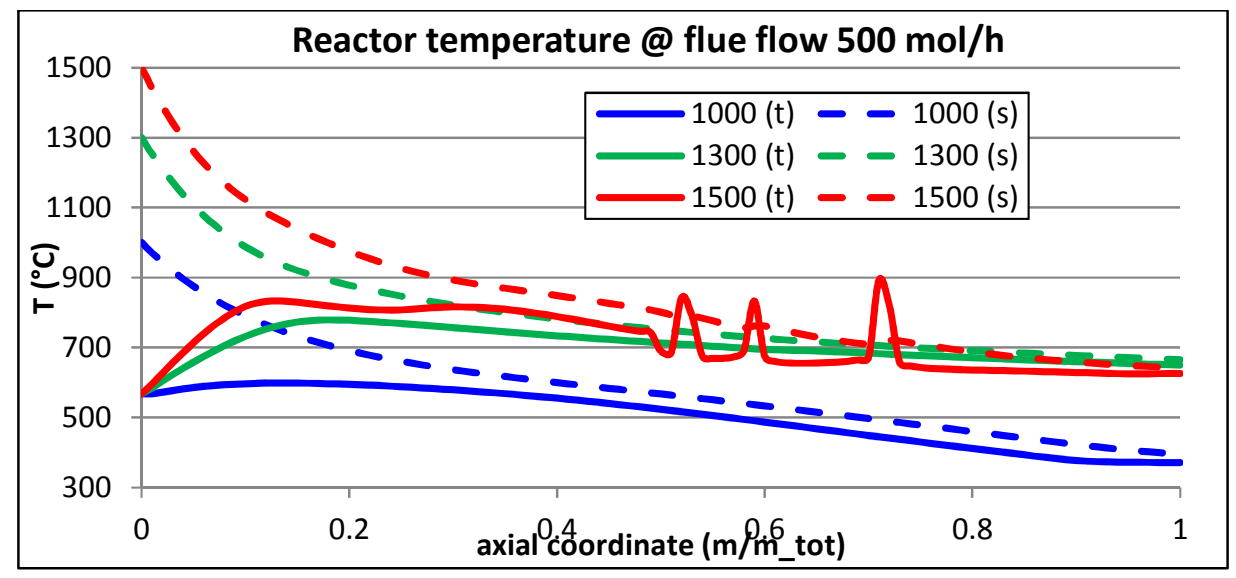

c)

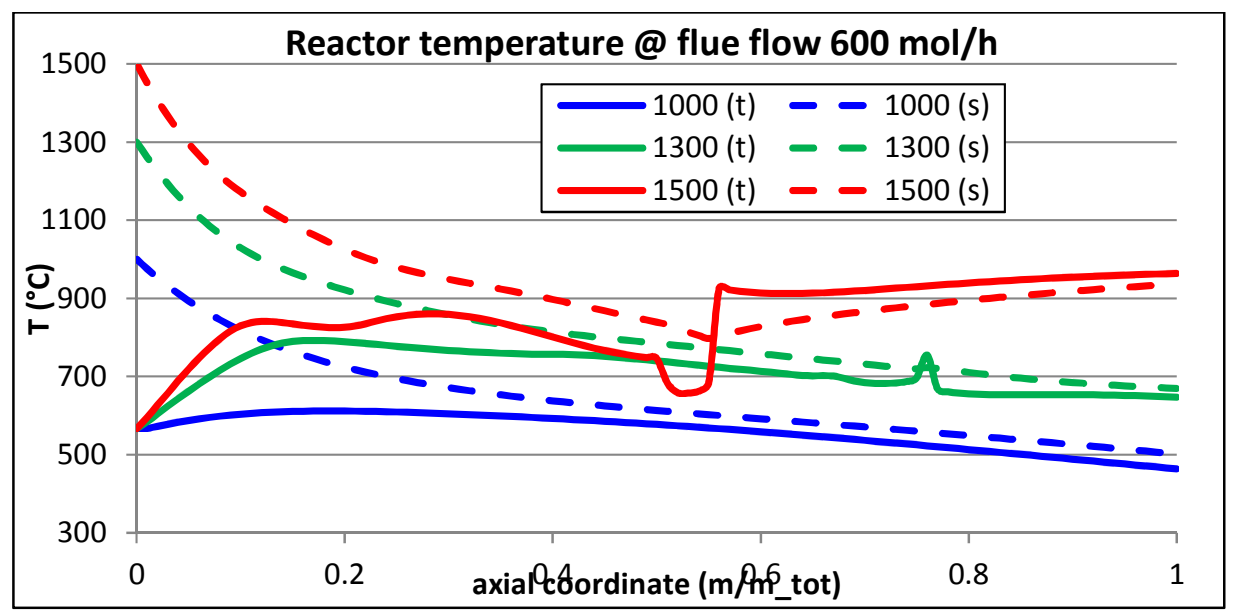

Figure 5a-b-c: Thermal profiles of the reactor along the axial coordinate at different flue flowrate. Solid line: tube-side, reacting mixture (cold fluid); dotted line: shell-side, service flue gas (hot fluid). Numbers in the legend indicates the hot fluid inlet temperature. In every case, the $\Delta \mathrm{T}$ between the fluids at the exit is $\geq 15^{\circ} \mathrm{C}$. A too high heat transfer determines inconsistent outlet conditions (the spikes mark the onset of thermal crossover). In all these open-tear simulation, the fuel cell utilization factor $\quad$ is 
Figure 6: Open-tear analysis of the flowsheet based on the reactor hydrogen yield (color scale bar), as function of the fractional enthalpy difference, represented as temperature (dT), and moleflow contributions between the flue gases fed to the reformer and those yielded back after splitting the burned gas. The convergence point is at the $(0,0)$ coordinate. The points shown are obtained for flue flows of 400, 500 and $600 \mathrm{~mol} / \mathrm{h}$. Tests lying the I (IV) quadrant let foresee an enthalpy build-up (depletion) within the flue recycle once the tear is closed.

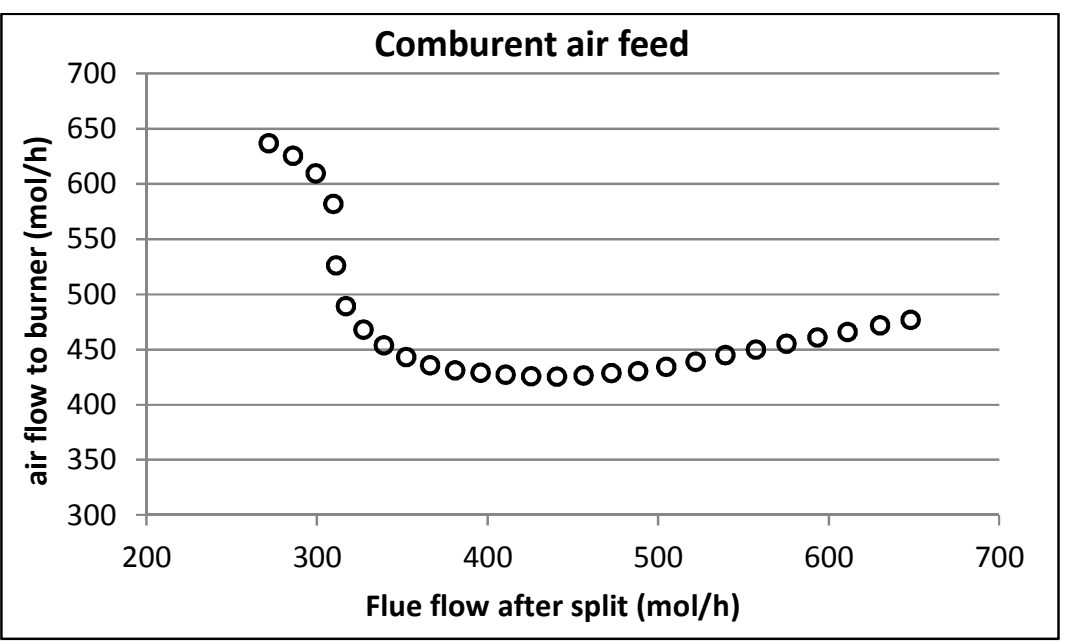

Figure 7: Air feed to the burner (calculated so that the oxygen flow is $110 \%$ of the stoichiometric quantity). The zone around $400 \mathrm{~mol} / \mathrm{h}$ is a shallow minimum good for operating purposes. 
a)

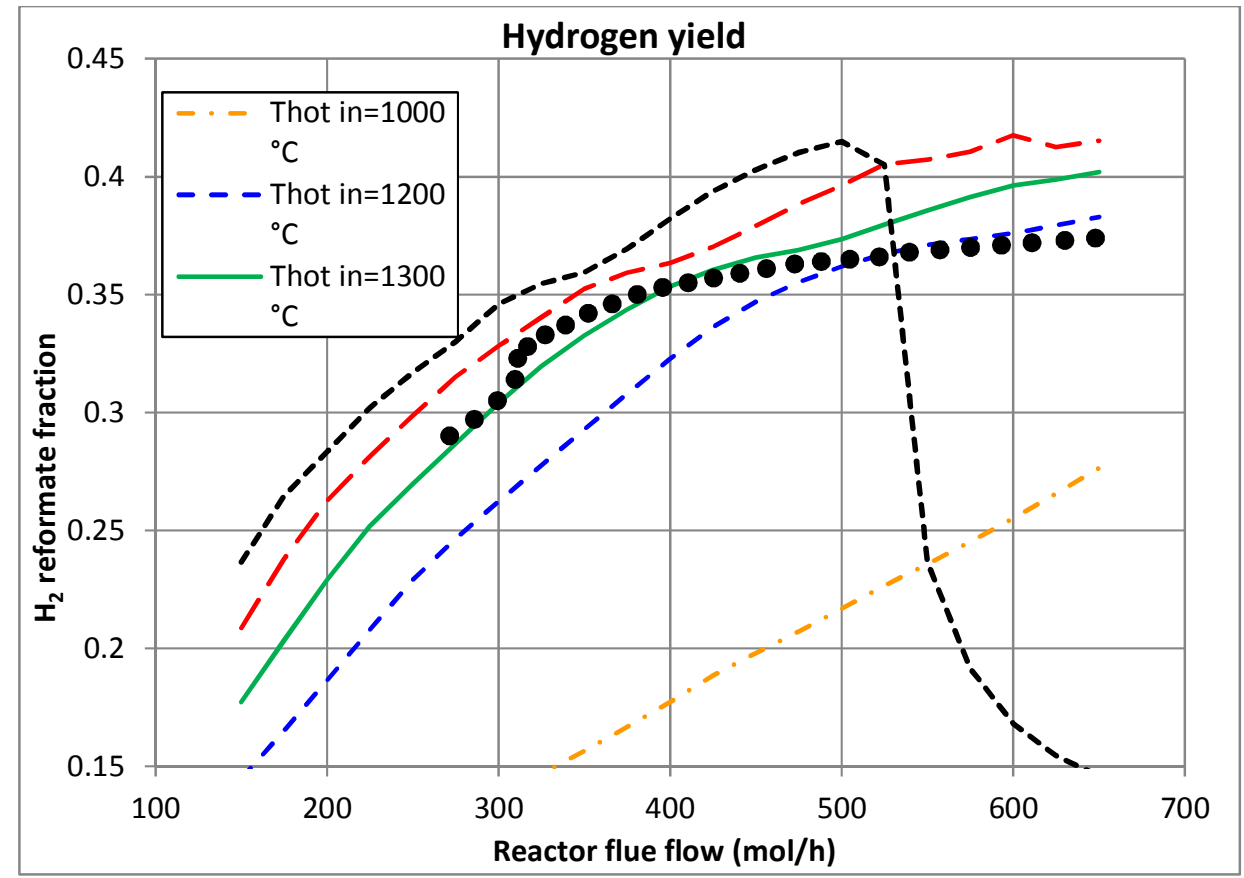

b)

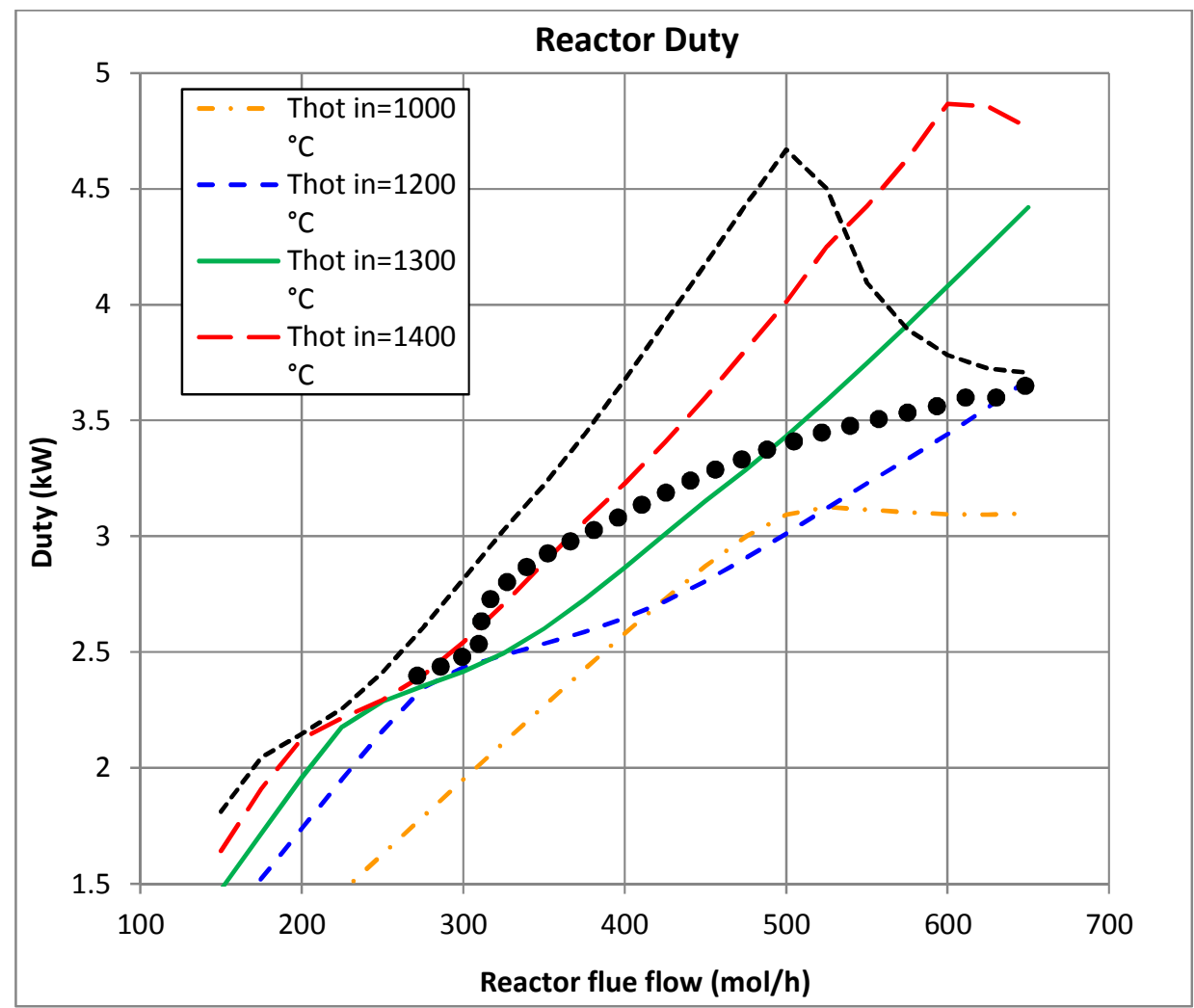

Figure 8a-b: Reformer hydrogen yield (a, top) traced at open flue recycle (lines) and then at different convergence conditions. Bottom, b: reformer heat duty at open flue recycle (lines) and then at different convergence conditions. 


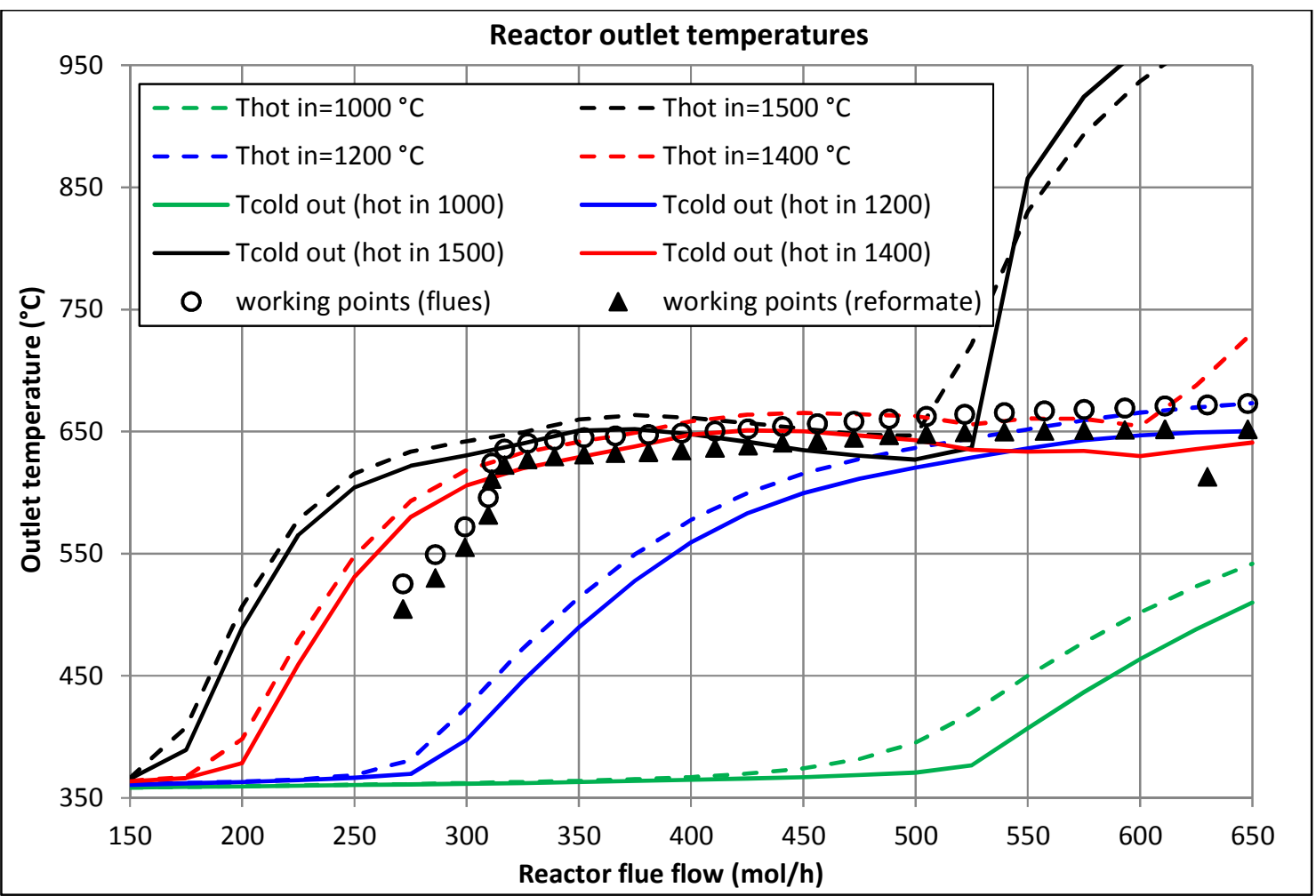

Figure 9: Outlet temperature from the reformer; lines: open recycle, tube side (solid) and shell side (dashed); points: closed loop, tube (filled) and shell (empty) sides. The ethanol-water inlet temperature is fixed at $567{ }^{\circ} \mathrm{C}$. 
Table of Contents

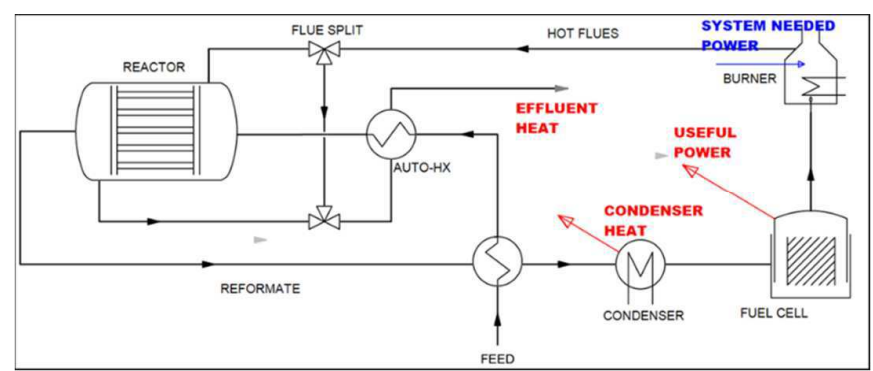

An integrated system based on fuel cells and fed with diluted bioethanol has been sized for sustainable micro-cogeneration of heat and power. 